\title{
Economic Growth and Total Factor Productivity in Lebanon
}

\author{
Wadad $\mathrm{Saad}^{1}$ \\ ${ }^{1}$ Professor at the Faculty of Economics and Business Administration, Branch 1- Lebanese University, Lebanon \\ Correspondance: Wadad Saad, Head of the Economics Department at the Faculty of Economics and Business \\ Administration, Branch 1- Lebanese University. Hadath, Lebanon. Tel: 96-1388-0036. E-mail: \\ wsaad96@hotmail.com
}

Received: December 9, 2016

Accepted: December 19, 2016

Online Published: January 10, 2017

doi:10.5539/ijef.v9n2p159

URL: http://dx.doi.org/10.5539/ijef.v9n2p159

\begin{abstract}
This study investigates empirically the determinants of economic growth and total factor productivity in Lebanon over the period 1980-2014. To do so, we firstly estimate the total factor productivity in a growth accounting framework. Secondly, an Autoregressive Distributed Lag (ARDL) modeling approach has been applied to examine the relationship between economic growth and some macroeconomic variables such as foreign direct investment, openness, claims on private sector, and official development assistance. Then we consider modeling the effects of these macroeconomic determinants on TFP through an ARDL model. Findings of the regression analysis suggest the presence of a statistically significant relationship between economic growth and the variables involved in this study except for claims on private sector which appears to be insignificant. The results of TFP model show a significant relationship with claims on private sector and openness on one hand and insignificant link with the direct foreign investment and official development assistance on the other hand.
\end{abstract}

Keywords: economic growth, total factor productivity, autoregressive distributed lag model, capital stock

\section{Introduction}

Lebanese economy has witnessed periods of significant economic growth and periods of severe recession. The massive economic and financial reforms that have been implemented since 1993 have impacted interestingly the economic growth. As a consequence, during the reform era, substantial efficiency gains could have been reaped from the reallocation of the resources to higher productivity sectors. Investing in major sources of Lebanese economic growth becomes a particular concern for policymakers.

Economic growth trend is assumed to be the result of factor accumulation and productivity change. Thus, studying economic growth necessitates analyzing the sources of economic growth over time. Moreover, analyzing the factors responsible for the surge in total factor productivity (TFP) experienced by the Lebanese economy in various periods is also an important issue. For instance, the use of trade openness and foreign direct investment as components of the TFP highlights the impact of foreign capital and technologies on improvements in TFP.

Most growth studies on the East Asian newly industrialized countries showed that their great success has largely driven by massive factor accumulation, rather than innovative activities and technological progress (Young, 1995; Wu, 2004).

Based on the entanglement between economic growth and productivity, this study aims to investigate the impact of some macroeconomic variables such as foreign direct investment, claims on private sector, official development assistance, and openness on real GDP and Total Factor Productivity. Assuming constant returns to scale, it is possible to compute the output growth resulting from the growth in input factors (capital stock and human capital) using a VECM model based on Solow's approach. Deviations of the actual output from the estimated one are attributed to changes in technology and other factors. These deviations are called growth in total factor productivity (TFP) and could encompass more than is suggested by the work productivity. They are also called residual or "Solow residual" in growth. Afterwards, two autoregressive distributed lag models are used to explore the sources of economic growth and TFP over the period 1980-2014.

This study is organized as follows: in section 2 we present an overview of the Lebanese economy. In section 3 we present the literature review that exposes the main thoughts concerning the analysis of economic growth and 
productivity. Section 4 is devoted to methodology and data that are used in this study. Section 5 reports the empirical results and essential findings. The study ends with a brief conclusion.

\section{Overview of the Lebanese Economy (Note 1)}

According to the statistics of the United Nations, Lebanon's economic growth over the past several decades has witnessed a period of high volatility and perturbation which was due to the civil war that ended in 1990. After this date, the economy has known a more or less stable situation except for the years 1996 and 1999 as a result of political events (see Figure 1). In these years, the economic growth was slightly below zero. However, the period between 2007 and 2010 has known a boost in economic growth due to the financial flow from abroad. The financial crisis in 2008 had a prosperous impact on economic growth since Lebanon was at a large extent, protected from the implications in this crisis. The reason for that is commercial banks in Lebanon were not heavily involved in this crisis. Thus, a large number of Arab investors and depositors transferred their money to Lebanon. The growth rate per capita was $9.34 \%$ in 2007 and $8.03 \%$ in 2010. Afterwards, growth rate per capita has declined to $0.92 \%$ in 2011 and then increased to $2 \%$ in 2014.

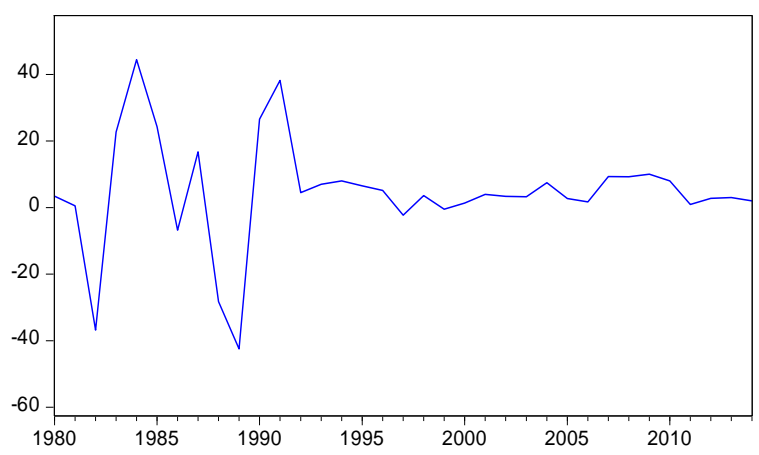

Figure 1. Economic growth per capita over the period 1980-2014

Before 1990, the lowest rates of growth were in 1982 and 1989. The former is referred to the Israeli invasion of Lebanon and the latter is because of the huge depreciation of the Lebanese pound as a result of the accumulated years of civil war that started in 1975 and ended in 1990. This war deteriorated Lebanon's economic infrastructure, cut national output by half, and reduced remarkably its position as Middle Eastern entrepot and banking hub. Following the civil war, Lebanon witnessed a period of rehabilitations and construction that led to rebuilt much of the war-torn physical and financial infrastructure. Although these activities were partially completed, the government was saddled with a huge debt burden that was mostly financed by borrowing from domestic banks.

Conferences were held by international donors during the 2000s in order to help Lebanon to overcome its economic problems in counterpart of pledges of economic and financial reforms. Paris I, II, and III are the most important conferences but have mostly gone unfulfilled.

In recent years, the conflict in Syria has resulted in 1.5 million refugees to Lebanon and a slowdown in the economic growth that went to the 1-2\% range in 2011-14, after four years of $8 \%$ average growth.

The Lebanese economy is an import-oriented economy and the export base remains small because of poor infrastructure, and unstable economic and political environment. The trade, expressed by the sum of imports and exports as percentage of GDP, was largely volatile between 1980 and 1992. Its lowest level was $0.69 \%$ in 1992 . Following this date, it increased slightly to reach $0.98 \%$ in 2009 and then slightly declined to $0.89 \%$ in 2014 .

Inward foreign direct investment (FDI) as percentage of GDP was relatively stable before 1996 within -0.2 and 0.6 range. Then it increased remarkable with high volatility between 1997 (11.7\%) and 2005 (15.5\%). Afterwards, this rate declined to $6.2 \%$ in 2014 .

Lebanese economy is also service-oriented. The most important growth sectors are banking and tourism. The banking sector has known several reforms in order to be in line with international financial norms. Lebanese banks were not affected by the financial crisis in 2008 due to prudent banking regulations and supervision, in addition to the conservative strategy followed by Lebanese banks. The capital requirements rules of Basel I and II have been implemented in the banking sector and Basel Capital Accord or 'Basel III' is taken its way to be accomplished by these banks. 


\section{Literature Review}

Economists have focused for decades on the sources of productivity in economic growth. Solow (1957) used an aggregate production for the American economy and calculated total factor productivity (TFP) growth as the residual resulting from subtracting labor and capital growth from output growth. His procedure is known as "growth accounting" and has applied to many countries. TFP measures the efficiency with which accumulated factors of production are used to produce final output.

In a standard aggregate production function, GDP depends on three factors: physical capital (K), labor (L), and stock of knowledge or total factor productivity (TFP). TFP is supposed to have two sources of growth: a domestic source that stems from innovations and an international one that is related to the capability of the country to absorb or imitate technological progress coming from leading countries. The rate of domestic innovation is related to the level of human capital (education) and imitation that is expressed by "catch-up" term. The speed of imitation will be faster in countries with low level of initial stock of knowledge than the ones with higher level of initial stock of TFP (Barro \& Sala-i-Martin, 1995, Ch.8).

One of the main implications of the empirical studies that are based on Solow's approach was to investigate to what extent output growth is sustainable in the future. From neoclassical point of view, growth models assume that economic growth (expressed by output per capita) has to be accompanied by continuous increases in TFP in order to be sustainable. This is due to the fact that factor accumulation shows evidence of decreasing returns that result in self defeating. However, different perspectives have been emerged regarding growth episodes. For instance, Krugman (1994) stipulates that East Asian growth was attributed to increase in input levels. Young (1995) found similar results concerning East Asian economic growth and argues that this latter is due to rapid factor accumulation rather than increases in TFP. Thus, assessing productivity growth and investigating why it occurs or not is a question of interpreting various growth episodes.

Moreover, the use of Solow's approach (1957) does not allow identifying sources of TFP growth. For instance, it does not reveal whether TFP growth stems from efficiency gains or from technological progress. For this reason, we will explore in Lebanon the impact of foreign direct investment (FDI), openness that is measured by the ratio of total exports plus imports to GDP, claims on private sector, and official development assistance (ODA) on TFP and GDP in order to infer some macroeconomic sources of these last variables.

The effect of openness on economic growth is a controversial issue. The empirical studies found conflicting results. Some of them found a positive impact of trade on economic growth such as Romer $(1986,1992)$, Lucass (1988), Grossman and Helpman (1991), and Barro and Sala-i-Martin (1995), while others found a negative or doubtful relationship such as Krugman (1994) and Rodrick (1995).

In addition, a strong financial sector leads to higher saving and consequently to higher economic growth. Financial deepening is proxied by the claims on private sector. Empirical studies such as King and Levine (1993a, 1993b), Beck, Levine, and Loayza (2000), and Benhabib and Spiegel (2000) show a positive relationship between financial development and economic growth, physical capital accumulation, and productivity growth.

Neoclassical model assumes that the long run growth can be achieved through technological progress and increase in population. As a result, the effect of FDI on growth can be noticed in the short run like the domestic investment. The endogenous growth model stipulates that FDI enhances total factor productivity which consequently stimulates economic growth through the transfer of advanced technology (Lichtenberg \& De la Potterie, 1996). It suggests that the accumulation of capital in the form of FDI generates, directly and indirectly, substantial spillover benefits (Ramirez, 2006).

Foreign aid that is represented by the official development assistance (ODA) plays a positive role on economic growth if it finances investment rather than consumption (Gupta, Pattillo, \& Wagh, 2005). The use of financial aid in financing infrastructure projects (rehabilitation of roads and vital facilities) and investment in human capital (education or health care) will be translated into limiting the strains on the domestic tax base. However, Rajan and Subramanian (2005) argue that aid does not appear to stimulate growth over the short and long term although the adoption of sound economic policies in certain countries.

However, classical and neoclassical models do not attempt to explain the contribution of technology transfer and innovations as an endogenous component of the growth process. They mainly rely on factor accumulation to explain economic growth.

To settle this issue we will estimate two autoregressive distributed lag models for economic growth and TFP that encompass the same for-mentioned variables. 


\section{Methodology and Data}

Two steps are used in order to get the total factor productivity (TFP): first, we estimate the production function and second we compute the TFP.

This study uses the standard Cobb-Douglas aggregate production function that is linking output to factor inputs (capital and labor) and productivity (along the lines of the neoclassical Solow-Swan model: see, for instance, Barro \& Sala-i-Martin, 2004):

$$
Y_{t}=A K_{t}^{\alpha} L_{t}^{\beta} \quad 0<\alpha<1 \text { and } 0<\beta<1
$$

Where $t$ is a time index, $Y$ is the real GDP, $K$ is the real capital stock, $L$ is the total employment, $\alpha$ is the contribution of capital to output, $\beta$ is the contribution of labor, and the expression $A$ is the TFP. TFP-technological progress and other elements that affect the efficiency of the production process, measures the shift in the production function at given levels of capital and labor. Since we are interested in growth in TFP, it is preferable to write equation (1) in terms of output per capita:

$$
T F P=A=Y /\left(K^{\alpha} L^{\beta}\right)
$$

The level of TFP can be computed by taking the logarithm of both sides of equation (2):

$$
\ln (T F P)=\ln A=\ln Y-(\alpha \ln K+\beta \ln L)
$$

Thus, the level of TFP is computed by subtracting the contributions of factors of production from the level of output, and the rate of TFP growth. Moreover, the rate of TFP growth can be computed by subtracting the contributions of factors from the rate of output growth or by calculating the rate of change in the level of TFP.

Capital stock series, $\mathrm{K}$, is constructing using perpetual inventory method:

$$
K_{t}=(1-\delta) K_{t-1}+I_{t}
$$

where $I_{t}$ is the gross fixed capital formation and $\delta$ is the depreciation rate $(0<\delta<1)$. The initial capital stock is estimated by using the following formula:

$$
K_{t}=\frac{I_{t}}{(g+\delta)}
$$

where $g$ is the average annual growth rate of the real GDP over the period 1980-2014 and $\delta$ is the depreciation rate and it is supposed equal to $5 \%$ annually.

To estimate the production function, we apply the Johansen (1988. 1990) multivariate cointegration over the period 1980-2014. A graphical presentation for real economic growth and TFP growth, both in logarithmic forms, is presented in figure (1).

\subsection{Models of GDP and TFP}

Growth theory has witnessed developments that have emphasized the importance of well functioning institutions (North, 1990; Hall \& Jones, 1999; and Acemoglu, Johanson, \& Robinson, 2001) and good policies in providing an environment that enhances economic development through accumulation of production factors and efficient use of resources. Many empirical studies have explored the impact of several macroeconomic variables on economic growth and TFP such as Ghura and Hadjimichael (1996), Elbadawi and Ndulu (1996), Sachs and Warner (1997), Collier and Gumming (1999), Wane (2004), and Pattillo, Gupta and Carey (2005). Based on these studies, a modified neoclassical growth model is estimated in order to explore the role of certain macroeconomic variables in determining economic growth:

where,

$$
\begin{gathered}
\ln G D P=\beta_{0}+\beta_{1} \text { lnclaim }+\beta_{2} \text { openness }+\beta_{3} O D A+\beta_{4} \ln F D I+e_{t} \\
T F P=\alpha_{0}+\alpha_{1} \text { lnclaim }+\alpha_{2} \text { openness }+\alpha_{3} O D A+\alpha_{4} \text { lnFDI }+u_{t}
\end{gathered}
$$

\footnotetext{
$\ln G D P \quad$ is the real GDP in logarithmic form

Inclaim is the claims on private sector in logarithmic form

openness is the sum of exports and imports taken as percentage of GDP

InODA is the official development assistance in logarithmic form

lnFDI is foreign direct investment in logarithmic form

TFP is the total factor productivity in logarithmic form
}

The estimations are carried out using annual time series data for the period 1980-2014. The data are collected from World Bank, international Monetary Fund, Lebanese Ministry of Finance, and Central bank of Lebanon. 
Values of the variables are expressed in 2005 constant prices.

There are many techniques that can be used to estimate cointegrating relationships on economic growth and TFP such as Engel and Granger (1987), Johansen and Juselius (1988, 1990). All these techniques require the same order of integration. When the variables have different order of integration, the estimation cannot be accurate. To handle this issue, Pesaran et al. (1999) proposed an Autoregresse distributed Lag model (ARDL) cointegration method. This technique does not require the variables to have the same order of integration. Two more advantages can be mentioned regarding this method: 1) it determines sufficient lags to capture data generating process by going from general to specific modeling; 2 ) it generates a dynamic error correction model through a simple linear transformation. The ARDL are estimated using EVIEWS software developed in by Quantitative Micro Software (QMS), now a part of IHS.

The economic growth equation represented by an ARDL model is written as follows:

$$
\begin{aligned}
& \Delta \operatorname{lnRGDP}_{t}=\beta_{0}+\sum_{\mathrm{t}=1}^{\mathrm{n}} \beta_{1 \mathrm{i}} \operatorname{LlnRGDP}_{t-1}+\sum_{\mathrm{t}=0}^{\mathrm{n}} \beta_{1 \mathrm{i}} \text { _lnclaim }_{t-1}+\sum_{\mathrm{t}=0}^{\mathrm{n}} \beta_{1 \mathrm{i}} \text { Dopeness }_{t-1}
\end{aligned}
$$

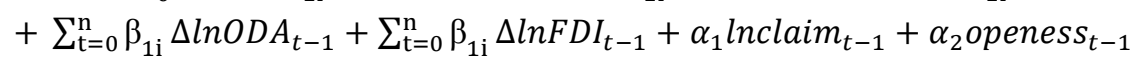

$$
\begin{aligned}
& +\alpha_{3} \ln O D A_{t-1}+\alpha_{4} \ln F D I_{t-1}+\varepsilon_{t}
\end{aligned}
$$

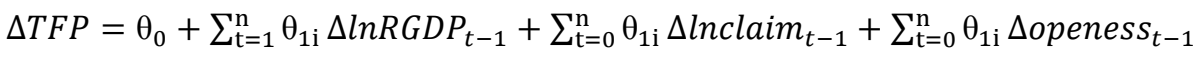

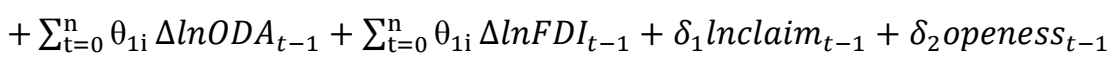

$$
\begin{aligned}
& +\delta_{3} \ln O D A_{t-1}+\delta_{4} \ln F D I_{t-1}+v_{t}
\end{aligned}
$$

where $\Delta$ is the first difference of the variable and $\varepsilon_{t}$ and $v_{t}$ ads the error terms. The unit root tests used in this study are Augmented Dickey Fuller (ADF) and Phillips-Peron (PP) tests.

The ARDL procedure is performed in two steps: a) determining the existence of a long run relationship among variables involved in this study. This consists of using Bound test of Pesaran and Shin (1999) and Pesaran et al. (2001) for large samples and Narayan et al. (2005) for small samples. These tests contain two types of critical values. The lower value is estimated if the variables are stationary at level $\mathrm{I}(0)$, and upper value is estimated if the variables are integrated of order one $\mathrm{I}(1)$. If the calculated F-statistic falls below the lower bound, then the null hypothesis $\mathrm{H}_{0}$ of no cointegration between the variables is not rejected. If it is higher than the upper bound, $\mathrm{H}_{0}$ is rejected. Finally, if it falls within the range, the result is inconclusive; b) determining the true dynamics of the model using Schwarz Bayesian Criterion (BSC) and performing the required tests to check the validity of the model.

Goodness of fit tests and diagnostic tests are taken into consideration in order to confirm the models' performance. Moreover, we used stability test suggested by Brown et al. (1975) (CUSUM and CUSUMSQ tests) since model instability and parameter inconstancy could results from inadequate modeling (Bahmani-Okooee, 2001).

\section{Results and Findings}

Using the standard Cobb-Douglas aggregate production, the level of TFP was estimated. A graphical depiction of the real GDP growth and TFP growth in logarithmic form is shown in Figure 2. This latter reveals strong fluctuations of the economic growth and the TFP between 1981 and 1990. Afterwards, the two variables show a relatively stable period. It is noticed that the two variables share a common trend and move consistently together over the study period.

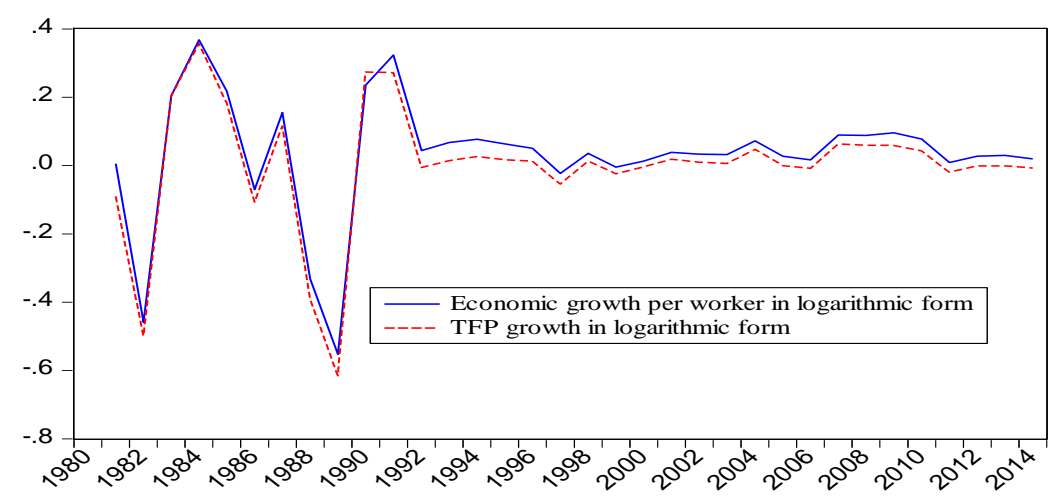

Figure 2. Economic growth and TFP growth over the period 1980-2014 
In the following section we will investigate the time series properties of all variables in order to estimate the two equations related to the economic growth and the total productivity function in Lebanon.

\subsection{Unit-Roots Tests}

The order of integration of the variables is investigated by using augmented-Dickey-Fuller (1981) (ADF) and Phillips-Perron (1988) (PP) tests. Table 1 reports the obtained results that show different order of integration among variables. Some variables are level stationary and others are stationary in first difference. Therefore, the use of Autoregressive Distributed Lag (ARDL) model to estimate the economic growth and TFP is justified. In addition, this procedure is more efficient than other techniques with limited sample data (30 to 80 observations), as suggested by Narayan et al. (2005). A graphical depiction for all variables is presented in Figure 3.

Table 1. Results of Augmented-Dickey-Fuller and Phillips-Perron tests

\begin{tabular}{|c|c|c|c|c|c|}
\hline \multirow{2}{*}{ Variable } & \multicolumn{2}{|c|}{ Augmented-Dickey-Fuller } & \multicolumn{2}{|c|}{ Phillips-Perron } & \multirow[t]{2}{*}{ order } \\
\hline & In level & In first difference & In level & In first difference & \\
\hline $\ln R G D P$ & -1.1792 & $-3.6043^{* *}$ & -2.7934 & $-7.0363 * * *$ & $\mathrm{I}(1)$ \\
\hline $\ln C L A I M$ & -3.0265 & $-4.7000 * * *$ & -3.3417 & $-4.6530 * * *$ & $\mathrm{I}(1)$ \\
\hline $\operatorname{lnFDILB}$ & -2.2513 & $-4.0297 * * *$ & -0.6225 & $-4.0831 * * *$ & $\mathrm{I}(1)$ \\
\hline OPENESS & $-3.8455^{* *}$ & & -1.9184 & & $\mathrm{I}(0)$ \\
\hline $\ln O D A$ & $-3.9307 * *$ & & $-3.8988 * *$ & & $\mathrm{I}(0)$ \\
\hline
\end{tabular}

$* * * * *$ denote significance at $5 \%$ and $1 \%$ respectively.

As stated before, the first step of ARDL model is to check if there is a long-run relationship between real GDP and its determinant on one hand and TFP and its determinants on the other hand. The results of the Bound test are presented in Table 2. The comparison of the F-statistic with the critical values of Bound test provided by Narayan (2005) indicates that we reject the null hypothesis of no long-run relationship between real GDP and its explanatory variables. Similarly, Bound test prove that there is a long-run relationship between TFP and its independent variables.

Table 2. Bound tests for economic growth and TFP models

\begin{tabular}{cccccc}
\hline Model & F-statistic & lag & I0 Bound & I1 Bound & significance \\
\hline LnRGDP & 10.2196 & 4 & 3.29 & 4.37 & $1 \%$ \\
TFP & 14.64012 & 4 & 3.29 & 4.37 & $1 \%$ \\
\hline
\end{tabular}

Null Hypothesis: No long-run relationship exists.

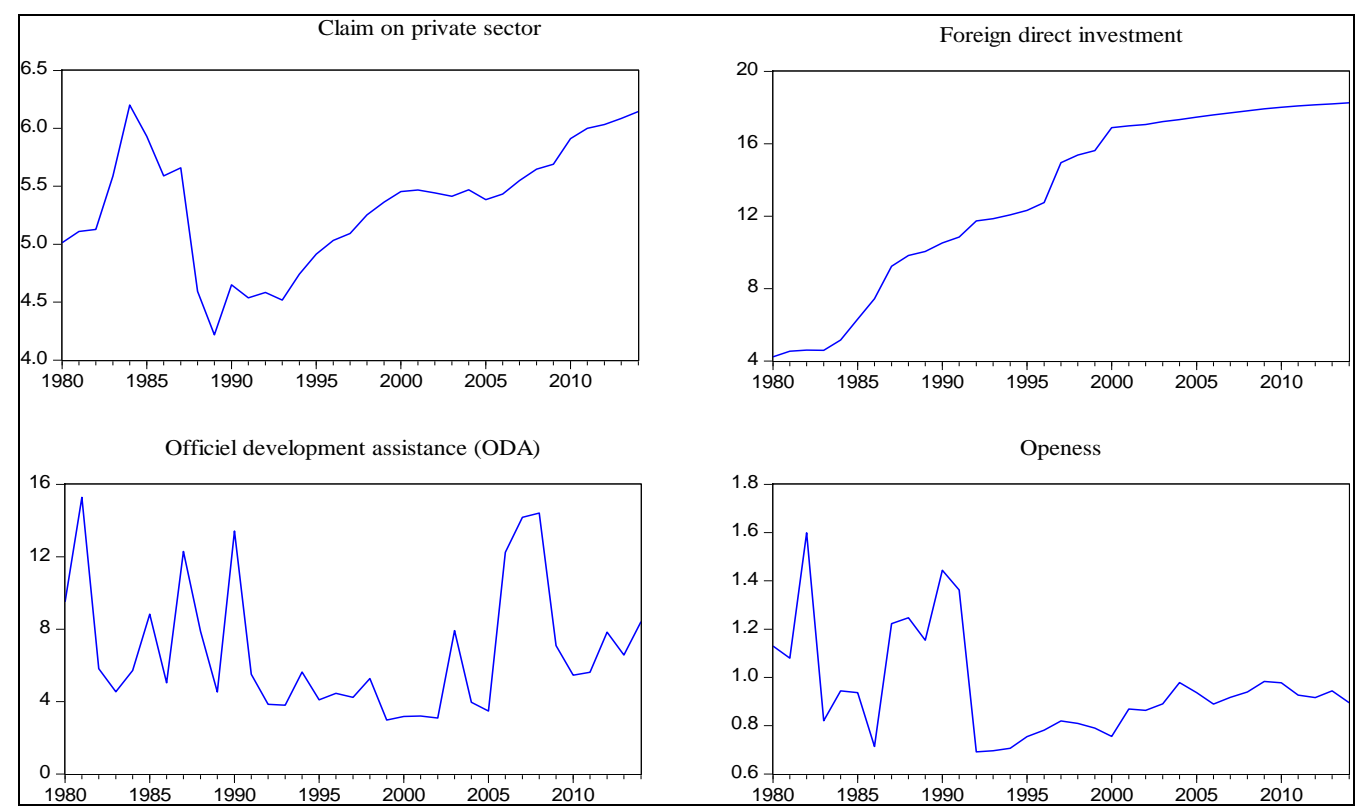

Figure 3. Evolution of selected macroeconomic variables in logarithmic form except for openness 


\section{Econometric Models}

The second step consists of estimating the long-run and the short-run (error correction) relationships. The optimum lag was chosen by using Schwarz Bayesian criterion (SBC) and Eviews software. The obtained results of each model will be presented in the following two sub-sections: economic growth model and TFP models. A dummy variable, that takes 0 for important political events and 1 otherwise, is used but it is found to be insignificant. Consequently, it was removed from both equations.

\subsubsection{Economic Growth Model}

The long-run and short-run equations for economic growth, with real GDP (in logarithmic form) as dependent variable, are reported in Table 3 and 4 respectively. The order of lag (n) in equation 7 is selected using Schwarz Bayesian Criterion (SC). Since we use annual data our estimations start with a maximum of 4 lags and choose the model that minimizes the value of SC. Eviews estimates an error correction version of the ARDL(4, 3, 0, 4, 4) accompanied with goodness of fit and diagnostic tests. This is specified as follows:

$$
\begin{gathered}
\Delta \ln R G D P_{t}=\beta_{0}+\sum_{\mathrm{t}=1}^{3} \beta_{1 \mathrm{i}} \Delta \operatorname{lnRGDP}_{t-1}+\sum_{\mathrm{t}=0}^{2} \beta_{1 \mathrm{i}} \Delta \operatorname{lnclaim}_{t-1}+\gamma \Delta \ln F D I_{t}+\sum_{\mathrm{t}=0}^{3} \beta_{1 \mathrm{i}} \Delta \text { openess }_{t-1}+ \\
\sum_{\mathrm{t}=0}^{3} \beta_{1 \mathrm{i}} \Delta \ln O D A_{t-1}+\alpha E C M_{t-1}+\varepsilon_{t}
\end{gathered}
$$

where $\alpha$ represents the error correction coefficient which measures the speed of adjustment to the long-run equilibrium, $\Delta$ is a first difference, and $\varepsilon_{t}$ is white noise error terms. A negative and significant coefficient of $E C M_{t-1}$ will be an indication of the existence of cointegration relationship among the variables.

The use of Bound test indicates the presence of long-run cointegration relationship (see Table 2). The long-run estimation of the economic growth is presented in Table 3. A positive and significant coefficient of FDI and openness at $1 \%$ and $5 \%$ respectively is considered. This is consistent with our expectation and previous studies. This means that an increase in the level of FDI and openness leads to an augmentation in the level of economic growth. Official development assistance (ODA) coefficient is negative and statistically significant at $10 \%$. However, the coefficient of claims on private sector appears to be statistically insignificant.

Table 3. Long-run estimated equation of the ARDL(4, 3, 0, 4, 4): real GDP model

\begin{tabular}{lccc}
\hline Dependent variable & real GDP $(\ln R G D P)$ & $t$-test & Prob. \\
\hline$C$ & 4.2588 & 3.1985 & $0.0085^{* * *}$ \\
InCLAIM & 0.1689 & 1.4848 & 0.1657 \\
InFDI & 0.0668 & 5.3788 & $0.0002^{* * *}$ \\
OPENESS & 4.9114 & 2.5499 & $0.0270^{* *}$ \\
InODA & -0.0864 & -1.8242 & $0.0954^{*}$ \\
\hline
\end{tabular}

$* * *, * *$, and $*$ indicate significance at $1 \%, 5 \%$, and $10 \%$, respectively.

The final stage in this ARDL model is to construct an error correction model (ECM). The results of the estimation are reported in Table 4.

Table 4. Error correction estimation for the selected ARDL(4, 3, 0, 4, 4) model: real GDP model

\begin{tabular}{lccc}
\hline Dependent variable & real GDP $D(\ln R G D P)$ & $t$-test & Prob. \\
\hline$D(\ln R G D P(-1))$ & 0.2035 & 1.9454 & $0.0777^{*}$ \\
$D(\ln R G D P(-2))$ & 0.4172 & 5.3208 & $0.0002^{* * *}$ \\
$D(\ln R G D P(-3))$ & 0.3299 & 4.0760 & $0.0018^{* * *}$ \\
$D(\ln C L A I M)$ & 0.5380 & 13.6275 & $0.0000^{* * *}$ \\
$D(\ln C L A I M(-1))$ & 0.4331 & 5.8576 & $0.0001^{* * *}$ \\
$D(\ln C L A I M(-2))$ & 0.1704 & 2.7345 & $0.0194^{* *}$ \\
$D(\ln F D I)$ & 0.0142 & 1.4857 & 0.1654 \\
$D($ OPENESS $)$ & 0.7292 & 8.4299 & $0.0000^{* * *}$ \\
$D($ OPENESS $(-1))$ & -0.3616 & -6.1295 & $0.0001^{* * *}$ \\
$D($ OPENESS $(-2))$ & -0.3325 & -6.6396 & $0.0000^{* * *}$ \\
$D($ OPENESS $(-3))$ & -0.1683 & -3.9034 & $0.0025^{* * *}$ \\
$D(\ln O D A)$ & 0.0005 & 0.2511 & 0.8064 \\
$D(\ln O D A(-1))$ & 0.0204 & 7.5913 & $0.0000^{* * *}$ \\
$D(\ln$ ODA $(-2))$ & 0.0164 & 5.7200 & $0.0001^{* * *}$ \\
$D(\ln O D A(-3))$ & 0.0101 & 4.5265 & $0.0009^{* * *}$ \\
ECM $(-1)$ & -0.2762 & -8.8169 & $0.0000^{* * *}$ \\
\hline
\end{tabular}

Note. $D$ denotes the change of a given variable. $* * *, * *$, and $*$ indicate significance at $1 \%, 5 \%$, and $10 \%$, respectively. 
We now proceed to interpret the parameter estimates for each variable pertaining to economic growth regression equation.

First of all, claims on private sector coefficients over the previous periods are positive and statistically significant. Financial development, represented by claims on private sector, has a strong positive effect on real GDP. This impact is reflected by a contemporaneous and a memory of two period's effect on the real GDP. This indicates that financial development plays an important role in supporting the economy in Lebanon in the short run. Lebanese banking sector is the most important provider of funds to the government since banks have more than $80 \%$ of the securities that finance the budget deficit in Lebanon. However, this support is not largely employed in the investment which explains the insignificance revealed in the long-run equation.

Second, FDI appeared to be insignificant in the short run and significant in the long run. This could be the results of the establishment of projects that have little effect on economic growth in the short run. However, the accumulation of these small improvements shows its impact on economic growth in the long run. Moreover, FDI is viewed as a tool of transferring skills, technology, and knowledge stock among countries (see Wooster \& Diebel, 2010). Consequently, FDI has been considered as an important channel for international knowledge transfer (see Keller, 2010). Since these tools take sometimes time to impact the economy, this explains the significance of FDI in the long run and not in the short run.

The ODA has a positive and significant effect on economic growth in the short run at and a negative impact on the long run at $1 \%$ and $10 \%$ level of significance respectively. This could be attributed to the fact that this aid wasn't completely directed to investments in infrastructure, rehabilitation and construction. The ODA has witnessed ups and downs during the study period (see Figure 3). The ups are attributed to periods of huge political events or wars that were characterized by large foreign aid to finance development. Figure 3 shows that ODA tends to be very volatile. The highest level of ODA was in 1990 which is the year of the end of civil war in Lebanon. The level in the recent period is far lower than the ones in 1981, 1990, and 2007.

Moreover, openness appeared to be positively and statistically significant at time $t$, like the long-run estimation, but negatively significant at the three previous periods of time. This is explained by the fact that Lebanon is mainly import-led and imports goods that are not in majority used in productive tasks and are addressed to final consumption. Figure 3 shows that in the period from 1980 to 1990 openness was very volatile. Afterwards, it has become more stable with a slight increase in values. The positive impact of the openness on the economic growth in the long-run results from the relatively small accumulation of the imported productive goods.

Finally, we notice that the coefficient of the ECM is negative and statistically significant at the $1 \%$ level of significance. The coefficient is equal to -0.2762 , indicating that the adjustment of short-run fluctuations towards the long-run equilibrium is at the rate of $27.62 \%$ annually.

The obtained results show also that economic growth has a memory of 1,2 , and 3 periods that affects the contemporaneous real GDP in a positive and statistically significant manner.

A number of diagnostic tests that are reported in Table 5 indicate that the short-run model has no serial correlation, heterskedasticity, and autoregressive conditional heteroskedasticity (ARCH) problems. The coefficient of determination $R^{2}$ implies that the model can explain 99.66 of the variation of the real GDP. Moreover, the residuals are normally distributed according to Jarque-Berra test.

Table 5. Diagnostic tests of the real GDP model

\begin{tabular}{lccccc}
\hline \multicolumn{5}{c}{ Diagnostic tests } \\
\hline Number of observations & 35 & Prob. & test & $F$-statistic & Prob. \\
\hline$R^{2}$ & 0.9966 & & Serial correlation & 0.6158 & 0.6238 \\
$D W$ & 2.3223 & & Heteroskedasticity & 0.3918 & 0.9648 \\
Normality & Jarque-Berra $=0.9903$ & 0.6094 & ARCH & 1.1749 & 0.2876 \\
\hline
\end{tabular}

The stability of this model is tested by using CUSUM (cumulative sum of recursive residual test) and CUSUM SQUARE (cumulative sum of square of recursive residual test). Plots of these two tests in Figure 3 (a and $b$ ) show that the CUSUM and CUSUM SQUARE tests stay within the 5\% significance level. Hence, the estimated coefficients are considered stable. 


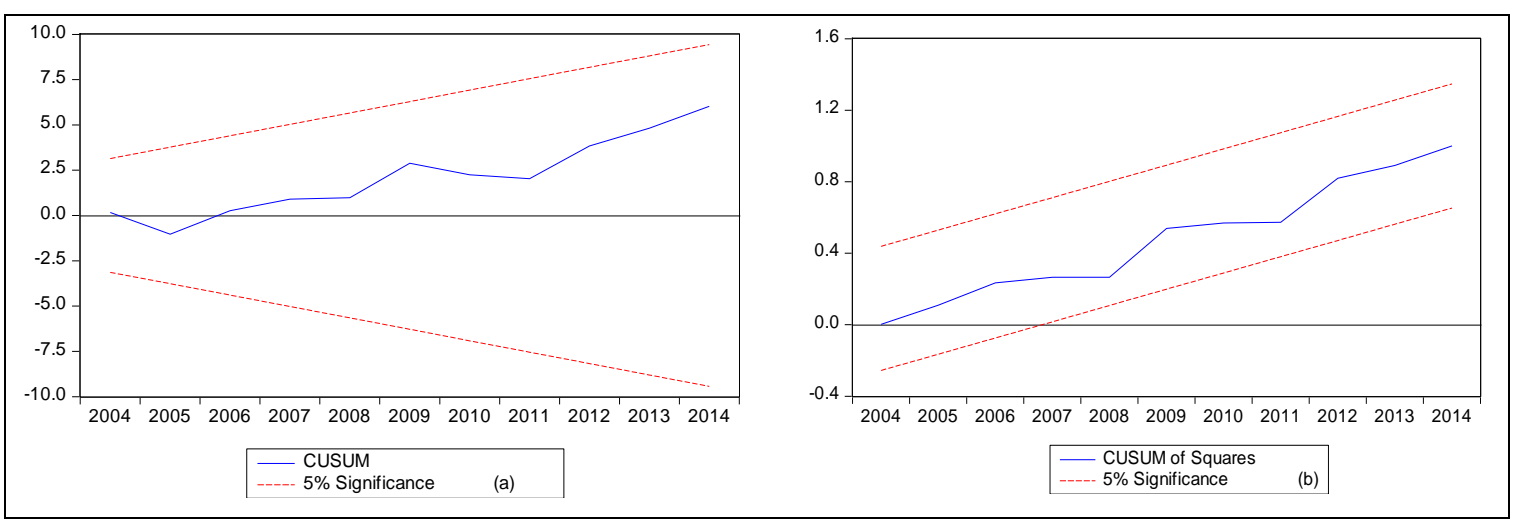

Figure 3. CUSUM and CUSUM SQUARE tests (economic growth model)

\subsubsection{TFP Model}

The long-run and short-run equations for TFP, with TFP (in logarithmic form) as dependent variable, are reported in table (6) and (7) respectively. Using Schwarz Bayesian Criterion, the specification chosen was that of an $\operatorname{ARDL}(4,3,0,4,4)$ accompanied with goodness of fit and diagnostic tests. The order of lag (n) in equation 8 is selected using Schwarz Bayesian Criterion (SC). Since we use annual data our estimations start with a maximum of 4 lags and choose the model that minimizes the value of SC. Eviews estimates an error correction version of the $\operatorname{ARDL}(4,3,0,4,4)$ accompanied with goodness of fit and diagnostic tests. This is specified as follows:

$$
\begin{aligned}
& \operatorname{lnTFP}_{t}=\lambda_{0}+\sum_{\mathrm{t}=1}^{3} \lambda_{1 \mathrm{i}} \Delta \operatorname{lnTFP} P_{t-1}+\sum_{\mathrm{t}=0}^{2} \lambda_{1 \mathrm{i}} \Delta_{\operatorname{lnclaim}_{t-1}}+\varphi \Delta \operatorname{lnFDI}_{t}+\sum_{\mathrm{t}=0}^{3} \lambda_{1 \mathrm{i}} \text { sopeness }_{t-1}+ \\
& \sum_{\mathrm{t}=0}^{3} \lambda_{1 \mathrm{i}} \Delta \operatorname{lnODA_{t-1}}+\beta E C M_{t-1}+u_{t}
\end{aligned}
$$

where $\beta$ represents the error correction coefficient which measures the speed of adjustment to the long-run equilibrium, $\Delta$ is a first difference, and $u_{t}$ is white noise error terms. A negative and significant coefficient of $E C M_{t-1}$ will be an indication of cointegration among the variables.

The use of Bound test indicates the presence of long-run cointegration relationship (see Table 2). We have different order of integration but none of the variables is stationary at its second difference $\mathrm{I}(2)$.

The long run estimated TFP model presented in table 6 reveals that the claims on private sector and openness are the key determinants of TFP. The coefficients of these variables are positive and statistically significant at $1 \%$ and 5\% respectively. This implies that in the long-run, an increase in these two variables is associated with an increase in the TFP. However, the coefficients of FDI and ODA are not significant, indicating no impact on the TFP in the long-run.

Table 6. Long-run estimated equation for $\operatorname{ARDL}(4,3,0,4,4)$ : TFP model

\begin{tabular}{lccc}
\hline Dependent variable & TFP $($ lnTFP $)$ & $t$-test & Prob. \\
\hline$C$ & -1.0190 & -1.7807 & 0.1026 \\
InCLAIM & 0.1649 & 3.3263 & $0.0068^{* * *}$ \\
InFDI & -0.0090 & -1.6304 & 0.1313 \\
OPENESS & 2.0471 & 2.5162 & $0.0287^{* *}$ \\
lnODA & -0.0351 & -1.7073 & 0.1158 \\
\hline * indicate significance at $1 \%, 5 \%$, and $10 \%$, respectively. & &
\end{tabular}

The short-run coefficient estimates reported in table 7 show that all variables are statistically significant, except for FDI. Coefficients of claims on private sector and ODA are positive and statistically significant. This implies that an increase in these variables is reflected in an increase in the TFP. As to openness, it has a contemporaneous positive and significant impact on TFP, but the three lagged periods of this variable has a negative and statistically significant effect on TFP. This is due to the large proportion of unproductive imports that do not lead to an improving impact on TFP. The error correction coefficient is negative and statistically significant at $1 \%$. This confirms once again the existence of a cointegration relationship among the variables involved in this model. It implies that after any external shock the system will converge to its long run equilibrium. The ECM 
coefficient is equal to -0.5529 , implying that deviations from the long-run equilibrium are corrected at a rate of $55.29 \%$ annually.

Table 7. Error correction estimation for the selected ARDL(4, 3, 0, 4, 4): TFP model

\begin{tabular}{lccc}
\hline Dependent variable & $D(\operatorname{lnTFP})$ & $t$-test & Prob. \\
\hline$D(\ln T F P(-1))$ & 0.3206 & 3.8388 & $0.0028 * * *$ \\
$D(\ln T F P(-2))$ & 0.4685 & 6.5521 & $0.0000 * * *$ \\
$D(\ln T F P(-3))$ & 0.4113 & 5.5330 & $0.0002 * * *$ \\
$D(\ln C L A I M)$ & 0.5231 & 14.3793 & $0.0000^{* * *}$ \\
$D(\ln C L A I M(-1))$ & 0.3888 & 6.4458 & $0.0000^{* * *}$ \\
$D(\ln C L A I M(-2))$ & 0.1047 & 2.0202 & $0.0684 *$ \\
$D(\ln$ FDI $)$ & -0.0023 & -0.2914 & 0.7762 \\
$D($ OPENESS $)$ & 0.6225 & 9.0614 & $0.0000^{* * *}$ \\
$D($ OPENESS $(-1))$ & -0.1783 & -3.9507 & $0.0023 * * *$ \\
$D($ OPENESS $(-2))$ & -0.2117 & -5.0576 & $0.0004 * * *$ \\
$D($ OPENESS $(-3))$ & -0.1002 & -2.7666 & $0.0183 * *$ \\
$D(\ln O D A)$ & 0.0014 & 0.7462 & 0.4712 \\
$D(\ln O D A(-1))$ & 0.0168 & 7.6539 & $0.0000 * * *$ \\
$D(\ln O D A(-2))$ & 0.0142 & 5.8923 & $0.0001 * * *$ \\
$D(\ln O D A(-3))$ & 0.0082 & 4.0912 & $0.0018 * * *$ \\
$E C M(-1)$ & -0.5529 & -10.8175 & $0.0000^{* * *}$ \\
\hline
\end{tabular}

Note. $D$ denotes the change of a given variable. ${ }^{* *}, * *$, and $*$ indicate significance at $1 \%, 5 \%$, and $10 \%$, respectively.

All the diagnostic tests that are reported in table 8 are justified. We notice that there is no autocorrelation among the error terms and the heteroskedasticity is absent. Furthermore, the residuals are normally distributed with respect to Jarque-Berra test. The coefficient of determination indicates that $99 \%$ of the variation in TFP is explained by the estimated model.

Table 8. Diagnostic tests of the TFP model

\begin{tabular}{cccccc}
\hline \multicolumn{5}{c}{ Diagnostic tests } \\
\hline Number of observations & 35 & Prob. & test & $F$-statistic & Prob. \\
\hline$R^{2}$ & 0.9903 & & Serial correlation & 0.1353 & 0.9362 \\
$D W$ & 2.0864 & & Heteroskedasticity & 0.5709 & 0.8634 \\
Normality & Jarque-Berra $=1.3963$ & 0.4975 & ARCH & 0.9480 & 0.3386 \\
\hline
\end{tabular}

A graphical representation of the stability test results (CUSUM and CUSUMQ) in Figure 4 show that the tests stay within the critical values lines, and then it can be concluded that TFP model is table.
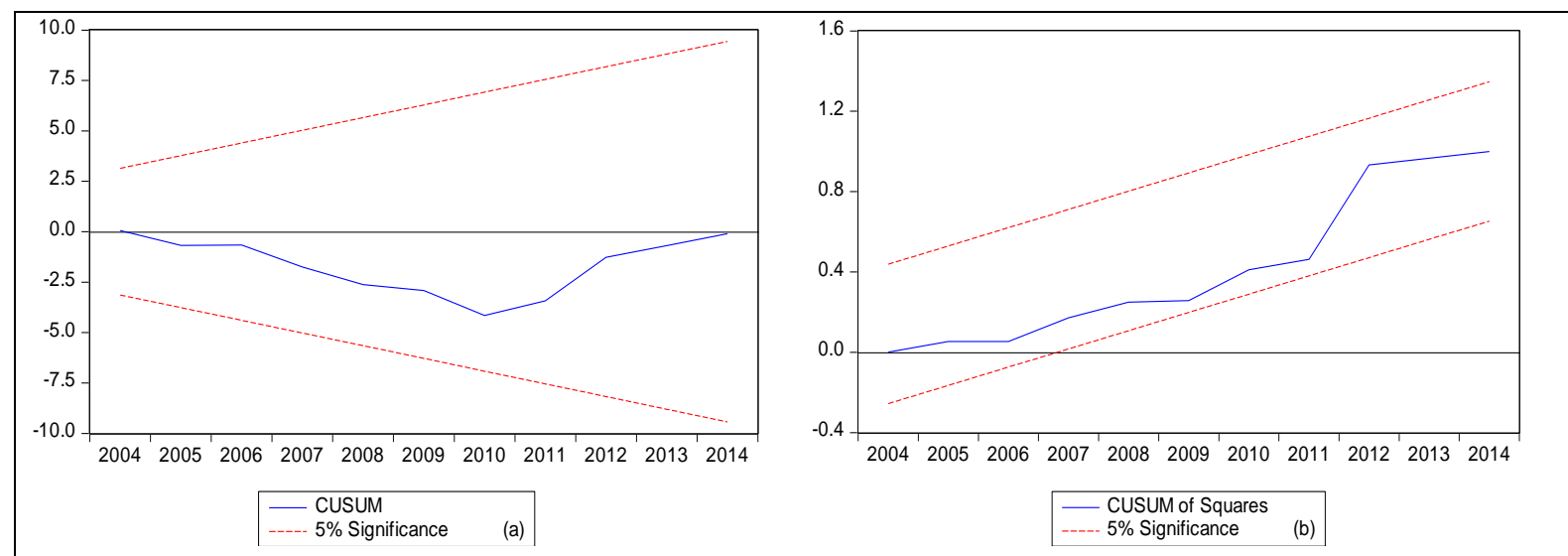

Figure 4. Plot of cumulative sum and cumulative sum of squares of recursive residuals: TFP model 
Finally, a dummy variable was used to take into account the effect of political events on economic growth and TFP. This variable was given a value "zero" in periods of perturbations and "one" elsewhere, but it was statistically insignificant in both equations; for this reason we remove it from the models.

\section{Conclusion}

Lebanon has an economy that mainly relies on services of different aspects with a financial sector that occupies the primary place among other sectors. Economic growth has consistently straining under public debt that hampered improving living standards. Lebanon is highly vulnerable to internal and external shocks, especially what is happening in the Middle East region from wars and political problems. A large volatility of the GDP was considered in the period 1980-1990. This was because of the civil war that took place from 1975 to 1990. Afterwards, the real GDP has increased consistently because of the process of rehabilitation and constructions that were undertaken by the government.

The aim of this study is to explore the sources of economic growth and total factor productivity. Macroeconomic variables such as claims on private sector, FDI, openness, FDI, and ODA are used as explanatory variables for these two variables.

In terms of methodology, this study adopts the ARDL cointegration technique in order to explore the sources of economic growth and total factor productivity. This latter variable was estimated by using a Cobb-Douglass production function over the period 1980-2014. The physical capital needed for the production function was calculated using the perpetual inventory method. The residuals of the production function represent the total factor productivity TFP.

Two ARDL models were used to explore the sources of the economic growth and TFP. The explanatory variables employed in these two models are claims on private sector, foreign direct investment, openness, and official development assistance.

The results show that openness has a positive impact on economic growth. Trade liberalization enhances competition and efficiency in production. It also allows technology transfer which also results in an increase in TFP. However, ODA has negatively affected economic growth. This means that foreign aid was used to finance consumption rather than investment. Lebanon has received large amounts of foreign aid, but these aids were not directed to finance development and investments in infrastructure. As to foreign direct investment (FDI), it shows a positive and highly significant impact on economic growth. FDI can affect economic growth in Lebanon through two channels: technology spillovers and physical capital accumulation. The interest in FDI stems from its employment generation capacity, its effect on productivity growth, and its dynamic link to competitiveness. In the contrary, claims on private sector show an insignificant effect on economic growth. This is due to the fact that about $80 \%$ of the public deficit is financed by the Lebanese banking sector. As a result, deposits in these banks are not directed in large amounts to investments.

Claims on private sector and openness show a positive and significant effect on TFP. Nevertheless, Aid flows and FDI reveal insignificant relationship with TFP.

All in all, this study highlights the importance of some macroeconomic variables on economic growth and TFP. It seems that openness plays an essentiel role in both economic growth and TFP. This is attributed to the fact that trading is conductive to direct transfers of technology when economies have a small stock of capital per worker in the early stages of development. This was the case of Lebanon which started a period of rehabilitation in 1993 after a civil war that lasted 15 years. Our empirical findings have important implications for Lebanese policymakers. It is important for them to control for the foreign aid which needs to be mainly directed to investment and to put into action strategies to reduce the budget deficit in order to profit from savings in productive projects rather than financing public deficits.

\section{Acknowledgement}

Acknowledgement: the authors would like to gratefully acknowledge the financial support provided by the National Council for Scientific Research -CNRS, Lebanon.

\section{References}

Acemoglu, D., Johnson, S., \& Robinson, J. A. (2001). The colonial origins of comparative development: An Empirical Investigation. American Economic Review, 91(12), 1369-1401. http://dx.doi.org/10.1257/aer.91.5.1369

Barro, R. J. (1995). Inflation and economic growth. Bank of England Quarterly Bulletin, 35(5), 166-76. https://doi.org/10.3386/w5326 
Barro, R. J., \& Sala-i-Martin, X. (2004). Economic Growth. Cambridge, Massachusetts: MIT Press.

Beck, T., Levine R., \& Loayza, N. (2000). Finance and the Sources of Growth. Journal of Financial Economics, 58(1), 261-300. http://dx.doi.org/10.1016/S0304-405X(00)00072-6

Benhabib, J., \& Spiegel, M. M. (2000). The Role of Financial Development in Growth and Investment. Journal of Economic Growth, 5(December), 341-60. https://doi.org/10.1023/A:1026599402490

Brown, R. L., Durbin, J., \& Evans, J. M. (1975). Techniques for testing the constancy of regression relationships over time. Journal of the Royal Statistical Society, 37, 149-163.

Collier, P., \& Gunning, J. W. (1999). Why has Africa grown slowly. Journal of Economic Perspectives, 13(3), 3-22. http://dx.doi.org/10.1257/jep.13.3.3

Dickey, D., \& Fuller, W. (1981). Likelihood Ratio Statistics for Autoregressive Time Series with a Unit Root. Econometrica, 6, 1057-72. http://dx.doi.org/10.2307/1912517

Elbadawi, A., \& Ndulu, B. (1996). Long-run development and sustainable growth in SubSaharan Africa. In New Directions in Development Economics: Growth, Environmental Concerns and Governments in the 1990s (London: Routledge).

Engle, R. F., \& Granger, C. W. J. (1987). Cointegration and Error Correction: Representation, Estimation and Testing. Econometrica, 55(2), 251-276. https://doi.org/10.2307/1913236

Ghura, D., \& Hadjimichael, M. T. (1996). Growth in Sub-Saharan Africa. IMF Staff Papers, 43(9), 605-34. http://dx.doi.org/10.2307/3867556

Grossman, G., \& Helpman, E. (1991). Innovation and Growth in the Global Economy. Cambridge: MIT Press.

Gupta, S., Pattillo, C., \& Wagh, S. (2005). Aid flows and donor practices: What do more than four decades tell us. Washington: International Monetary Fund.

Hall, R. E., \& Jones, C. I. (1999). Why do some countries produce so much more output per worker than others. Quarterly Journal of Economics, 114(2), 83-116. http://dx.doi.org/10.1162/003355399555954

Johansen, S., \& Juselius, K. (1990). Maximum Likelihood Estimation and Inference on Cointegration with Applications to the Demand for Money. Oxford Bulletin of Economics and Statistics, 52(5), 169-210. https://doi.org/10.1111/j.1468-0084.1990.mp52002003.x

Johansen, S. (1988). Statistical analysis of cointegration vectors. Journal of Economic Dynamics and Control, 12(June-September), 231-54. http://dx.doi.org/10.1016/0165-1889(88)90041-3

Keller, W. (2010). International Trade, Foreign Direct Investment, and Technology Spillovers. In B. Hall, \& N. Rosenberg (Eds.), Handbook of the Economics of Innovation. Elsevier North-Holland. http://dx.doi.org/10.1016/S0169-7218(10)02003-4

King, R., \& Levine, R. (1993a). Finance and growth: Schumpeter might be right. Quarterly Journal of Economics, 108(8), 717-38. http://dx.doi.org/10.2307/2118406

King, R., \& Levine, R. (1993b). Finance, entrepreneurship, and growth: Theory and evidence. Journal of Monetary Economics, 32(12), 513-42. https://doi.org/10.1016/0304-3932(93)90028-E

Krugman, P. (1994). The myth of Asia's miracle. Foreign Affairs, 73(November/December), 62-78. https://doi.org/10.2307/20046929

Lichtenberg, F., Van Pottelsberghe, \& Potterie, B. (1996). International R\&D spillovers: a re-examination. NBER Working Paper No. 5688. https://doi.org/10.3386/w5668

Lucas, R. E. (1988). On the mechanics of economic development. Journal of Monetary Economics, 22(2), 3-42. http://dx.doi.org/10.1016/0304-3932(88)90168-7

Narayan, P. K. (2005). The saving and Investment Nexus for China: Evidence from Cointegration. Applied Economics, 37, 1979-1990. http://dx.doi.org/10.1080/00036840500278103

North, D. (1990). Institutions, institutional change and economic performance. Cambridge University Press. http://dx.doi.org/10.1017/CBO9780511808678

Pattillo, C., Gupta, S., \& Carey, K. (2005). Sustaining and Accelerating Pro-Poor Growth in Africa. Washington: International Monetary Fund.

Pesaran, M. H., Shin, Y., \& Smith, R. J. (2001). Bounds Testing Approaches to the Analysis of Level Relationships. Journal of Applied Econometrics, 16, 289-326. http://dx.doi.org/10.1002/jae.616 
Pesaran, M. H., \& Shin, Y. (1999). An Autoregressive Distributed Lag Modeling Approach to Cointegration Analysis. In S. Strom (Ed.), Econometrics and Economic Theory in the 20th Century. The Ragnar Frisch Centennial Symposium, Cambridge: Cambridge University Press. https://doi.org/10.1017/CCOL521633230.011

Phillips, P. C. B., \& Perron, P. (1988). Testing for a Unit Root in Time Series Regressions. Biometrika, 75(1), 335-46. http://dx.doi.org/10.1093/biomet/75.2.335

Rajan, R., \& Subramanian, A. (2005). Aid and growth: What does the cross-country evidence really show. IMF Working Paper 05/127 Washington: International Monetary Fund. http://dx.doi.org/10.5089/9781451861464.001

Ramirez, M. D. (2006). Does Foreign Direct Investment Enhance Labor Productivity Growth in Chile? A Co-integration Analysis. Eastern Economic Journal, 32(2), 205-220.

Rodrik, D. (1995). Trade policy and industrial policy reform. In J. Behrman, \& T. N. Srinivasan (Eds.), Handbook of Development Economics (Vol. 3B, pp. 2925-82). Amsterdam: North Holland.

Romer, P. M. (1992). Two strategies for economic development: Using ideas and producing ideas. World Bank Annual Conference on Economic Development, Washington, DC, The World Bank. http://dx.doi.org/10.1093/wber/6.suppl_1.63

Romer, P. L. (1986). Increasing Returns and Long-Run Growth. Journal of Political Economy, 94(10), 1002-37. http://dx.doi.org/10.1086/261420

Sachs, J. D., \& Warner, A. M. (1997). Sources of slow growth in African economies. Cambridge, Massachusetts: Harvard Institute for International Development. http://dx.doi.org/10.1093/oxfordjournals.jae.a020932

Solow, R. M. (1957). Technical change and the aggregate production function. Review of Economics and Statistics, 39(8), 312-20. https://doi.org/10.2307/1926047

Solow, R. (1956). A contribution to the theory of economic growth. Quarterly Journal of Economics, 70, 65-94. http://dx.doi.org/10.2307/1884513

The World Bank. (1993). The East Asian miracle: Economic growth and public policy. New York: Oxford University Press.

Wane, A. (2004). Growth and convergence in the WAEMU. IMF Working Paper, 04/198. Washington: International Monetary Fund.

Wooster, R. B., \& Diebel, D. S. (2010). Productivity Spillovers from Foreign Direct Investment in Developing Countries: A Meta-Regression Analysis. Review of Development Economics, 14(3), 640-655. https://doi.org/10.1111/j.1467-9361.2010.00579.x

Wu, Y. (2004). China's Economic Growth. A miracle with Chinese Characteristics. London and New York: Routledge Curzon.

Young, A. (1995). The tyranny of numbers: Confronting the statistical realities of the East Asian growth experience. Quarterly Journal of Economics, 110(3), 641-680. http://dx.doi.org/10.2307/2946695

Bahmani-Oskooee, M. (2001). How stable is M2 money demand function in Japan? Japan and the World Economy, 13, 455-461. http://dx.doi.org/10.1016/S0922-1425(01)00064-0

\section{Note}

Note 1. All the numbers are taken from the bulletins of the Central Bank of Lebanon for the period 1985-2014. We used also the database of the ministry of finance in Lebanon for the period 1992-2014. We referred also to United-Nations for more data.

\section{Copyrights}

Copyright for this article is retained by the author(s), with first publication rights granted to the journal.

This is an open-access article distributed under the terms and conditions of the Creative Commons Attribution license (http://creativecommons.org/licenses/by/4.0/). 